\title{
PRODUCTION AND ECONOMIC PERFORMANCES OF THE RAINBOW TROUT BREEDING ON SERBIAN FISH FARMS WITH WATER OXYGENATION
}

\author{
Stevan Čanak', Zorica Vasiljević2 ${ }^{2}$ Ibrahim Totic ${ }^{3}$
}

\begin{abstract}
Summary
An interest for the rainbow trout production is in expansion in Serbia in recent years. When they make plans for investments, the potential investors into the trout production are usually faced with decision what is optimal size of production they are going to establish. In order to make proper decision, they have to know data on the production and economic performances that could be realized with different production volumes. Unfortunately, the literature on economic parameters dealing with the rainbow trout production is not very rich. This paper is dealing with economic aspects of the rainbow trout production in the conditions of the modern technology utilization that assumes use of water oxygenation.
\end{abstract}

The research subject of the paper is comparison between economic results of the various size trout farms dealing with production of market size trout. For the purposes of this analysis it was used the method of analytical calculation. In the analysis there were defined two production models, M1 model with annual production of 50 tons and M2 model with annual production of 150 tons of table rainbow trout.

The results of analysis showed that the M2 model has better economic parameters. In the structure of total production costs, the dominant share has feed (50\%), while the labor costs of the full-time employees are in second place (20\%). If the Serbian producers want to improve the economic performances of trout production, it is primarily necessary to be reduced the costs of these two items (feed and labor costs).

Key words: rainbow trout, production conditions, economic effects, water oxygenation

JEL: L23, Q19

1 Stevan Čanak, Ph.D., Assistant, Department for Chemical-Technological sciences, State University of Novi Pazar, Vuka Karadžića Street nn., 36300 Novi Pazar, Republic of Serbia, Phone: +381 20317 752, E-mail: scanak@np.ac.rs

2 Zorica Vasiljević, Ph.D., Full Professor, Faculty of Agriculture University of Belgrade, Nemanjina Street no. 6, Zemun, Republic of Serbia, Phone: +381 112615315 / Ext. 412, E-mail: vazor@agrif.bg.ac.rs

3 Ibrahim Totić, Ph.D., Assistant professor, Department for Economic sciences, State University of Novi Pazar, Vuka Karadžića Street nn., 36300 Novi Pazar, Republic of Serbia, Phone: +381 20317 752, E-mail: itotic@np.ac.rs

EP 2015 (62) 3 (599-612) 


\section{Introduction}

On the cold-water fish farms in Serbia it has been produced the rainbow trout (Oncorhynchus mykiss) as the table fish, while the brown trout (Salmo trutta) and Danube salmon (Hucho hucho) have been produced for restocking of open waters natural watercourses.

The typical size of rainbow trout in Serbia is between $250 \mathrm{~g}$ and $400 \mathrm{~g}$, whereas they are sold fresh on ice. Contrary to developed countries of Europe (Disegna et al., 2009) in Serbia there have not been still produced the organic trouts.

The trout is breeding in Serbia in two ways: with the spring water and with the river/stream water. The breeding based on spring water is characterized by lower variations in temperature, as well as less variation of available water quantity during the year. On the other hand, the use of river water for trout breeding is associated with very large changes in temperature $\left(0^{\circ} \mathrm{C}-20^{\circ} \mathrm{C}\right)$ and drastic changes in flow rates during the year. Particularly sensitive period in the trout production represents the summer (June-September) when at the same time the water flow rates are the lowest and the temperatures are the highest. This phenomenon represents the greatest problem in successful trout breeding with the river water. In addition to low water levels in the summer, there is often present flooding in the spring and autumn period as well, which more often causes the considerable economic damages in the trout fisheries like in the year 2014.

The fish farms for trout breeding in Serbia according to the type are mostly the flow-through systems, and according to the way of construction they are the concrete ones (so-called the raceway basins or raceways). There are also several cage systems fish farms (Zaovine Lake, Lisinsko Lake), but production on them is proportionally small.

The size of trout farms in Serbia can be expressed on the basis of the volume and number of basins, as well as on the basis of production volume. According to the production, there are fish farms which produce less than $100 \mathrm{~kg}$ of trout, as well as those whose annual production amounts to 150-200 t. According to the completeness of the production process, there are the full-systemic farms that begin production with spawning of broodstock as well as the semisystemic ones that begin production with purchasing of some fry or fingerlings.

In general, the trout farming in Serbia is characterized by very large fluctuations in production conditions, then in the size of the ponds and in the quantity of produced fish. Compared to the neighboring countries, the conditions for the trout production in Serbia can be assessed as the acceptable ones. As a major disadvantage it can be stressed the absence of sufficient quantities of quality water, stable flow rate and the temperature during the year.

The research subject of this paper is comparison between the economic results of the various size trout ponds in Serbia dealing with production of market size trout. For the purposes of this analysis it was used the method of analytical calculation, wherein the essential factors are the production circumstances (primarily the water quality and type of the fish breeding). 


\section{Material and Methods}

The main goal of this paper is to analyze the production and economic results on the rainbow trout farms in Serbia in the case of two production models, on the basis of average production conditions and applied technology for rainbow trout breeding with water oxygenation.

The analysis given in the paper has been primarily based on the data collected by the interview carried out on three rainbow trout fish farms in Serbia. There were used average values for the several years' period. Three analyzed farms annually produce over 250 tons of rainbow trout, which represents over $25 \%$ of the Serbian production recorded in the past 5 years. On the basis of the average values referring to the rainbow trout production in different farms, there were made the analytical calculations with the basic absolute and relative economic parameters (value of production, operating costs, financial result, the production efficiency and profitability). Comparison of achieved economic results between the farms was done at the level of realized financial results, production efficiency and profitability.

In analysis there were defined two production models: the first model with 50 tons of the market size rainbow trout annual production (M1 model) and the second one with 150 tons (M2 model).

In this paper it was also used the domestic and foreign relevant literature, the secondary results of case studies and resources available on the Internet (RZS, 2015; FAO Fisheries and Aquaculture Department, 2015). The available data were analyzed using the "desk research" method, analysis and synthesis and method of analytical calculation.

\section{Production Results}

According to available data, the production of the trout farms in Serbia is carried out on the exploitation surfaces between $33,255 \mathrm{~m}^{2}$ and $42,639 \mathrm{~m}^{2}$. Volume of the basins in which the production is performed is nearly as much as the volume because the biggest part of the area $(>85 \%)$ is occupied by the basins for fattening with the average depth between $1 \mathrm{i} 1.1 \mathrm{~m}$, while the basins for fry are mainly of a depth between $0.6 \mathrm{~m}$ and $0.8 \mathrm{~m}$.

Table 1: Production on trout farms in Serbia in the period 2009-2013

\begin{tabular}{|l|c|c|c|c|c|c|}
\hline Indicator/Year & $\mathbf{2 0 0 9}$ & $\mathbf{2 0 1 0}$ & $\mathbf{2 0 1 1}$ & $\mathbf{2 0 1 2}$ & $\mathbf{2 0 1 3}$ & $\begin{array}{c}\mathbf{2 0 0 9} \\
\mathbf{2 0 1 3}\end{array}$ \\
\hline Total production $(\mathrm{kg})$ & $1,067,832$ & $1,065,966$ & 970,960 & 983,139 & $1,003,991$ & $1,018,378$ \\
\hline $\begin{array}{l}\text { Production for consumption- sold } \\
(\mathrm{kg})\end{array}$ & 880,051 & 873,047 & 795,925 & 807,849 & 854,916 & 842,358 \\
\hline Total area* $\left(\mathrm{m}^{2}\right)$ & 35,792 & 36,791 & 33,255 & 36,302 & 42,639 & 36,956 \\
\hline
\end{tabular}




\begin{tabular}{|l|r|r|r|r|r|r|}
\hline Indicator/Year & \multicolumn{1}{c|}{$\mathbf{2 0 0 9}$} & \multicolumn{1}{c|}{$\mathbf{2 0 1 0}$} & \multicolumn{1}{c|}{$\mathbf{2 0 1 1}$} & \multicolumn{1}{c|}{$\mathbf{2 0 1 2}$} & \multicolumn{1}{c|}{$\mathbf{2 0 1 3}$} & $\begin{array}{c}\mathbf{2 0 0 9}- \\
\mathbf{2 0 1 3}\end{array}$ \\
\hline Area of fattening basins* $\left(\mathrm{m}^{2}\right)$ & 30,610 & 31,844 & 28,489 & 31,113 & 37,173 & 31,846 \\
\hline $\begin{array}{l}\text { Production of table trout per } \mathrm{m}^{2} \\
\text { of fattening basins }\end{array}$ & 28.8 & 27.4 & 27.9 & 26.0 & 23.0 & 26.6 \\
\hline Production of table trout per $\mathrm{m}^{2}$ Total & 24.6 & 23.7 & 23.9 & 22.3 & 20.1 & 22.9 \\
\hline
\end{tabular}

*Area in exploitation

Source: Calculated on the basis of RZS, 2015 \& FAO Fisheries and Aquaculture Department, 2015.

The production of table trout in Serbia in the last five years amounted between $795,925 \mathrm{~kg}$ (2012) and 880,051kg (2009) according to the sold fish quantities (RZS, 2015 \& FAO Fisheries and Aquaculture Department, 2015).

In the calculations and presentation of achieved production per area unit, there can be used different data concerning the production indicator, such as the quantity of produced young fish of different age groups, then the quantity of totally produced fish for consumption, as well as the quantity of produced and sold market size fish in a calendar year. Similarly, for the area of the trout fish basins there can be used data for the total area of the basins, then the basin area for the production of different trout age categories, as well as the exploitation areas by particular years.

The quantity of table rainbow trout that is produced and sold annually in Serbia amounted to 796t-880t in the analyzed five-year period, with an annual average of $842 \mathrm{t}$. This production was realized on the fattening basins area between $28,489 \mathrm{~m}^{2}$ and $37,173 \mathrm{~m}^{2}$. Although the increase of areas under the trout farms is very limited in industrial countries for a long time due to the use of water and environmental issues (Lukowics, 1994; Wedekind et al., 2001; Fornshel, 2002), the areas under the trout farms could be increased in Serbia by 3-5 times (Markovic et al., 2011).

Production of table fish per area unit of the basin for fattening was between $23.0 \mathrm{~kg} /$ $\mathrm{m}^{2}$ and $28.8 \mathrm{~kg} / \mathrm{m}^{2}$, with an average of $26.6 \mathrm{~kg} / \mathrm{m}^{2}$. The indicator of production per production capacity unit area provides information on the intensity degree of the trout breeding in the phase of fattening. On the other hand, the production of table fish per total area unit indicates the total engaged production capacities for the production of market size fish and in analyzed period it amounted to $23 \mathrm{~kg} / \mathrm{m}^{2}$ in an average. There are also cases where trout farms achieved production higher than $50 \mathrm{~kg} / \mathrm{m} 3$ (Markovic et al., 2009).

The shown production refers to Serbia as a whole and it is conditioned by a series of problems the trout farming is facing with (insufficient quantity of water in the summer time, poor financial position of producers, difficulties in selling of fish and payments).

In addition to the results presented, there are fish farms that achieve significantly better production results. These are the fish farms that have much better natural 
conditions for fish breeding (quantity and quality of water) or they have modern systems for water oxygenation.

According to the amount of fish produced, the tree analyzed fishponds - "DB FOOD” - R1 (44' 2'12.76”N, 19³8'20.44’E), “Mri-Tech” - R2 (4353'47.30”N,

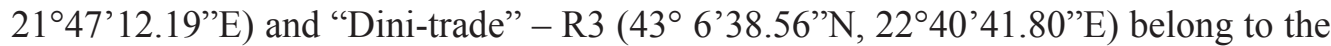
group of significant trout producers in Serbia, while according to the way of production they belong to the group of very modern and intensive trout fish farms in domestic circumstances (DB FOOD, 2015; Dini-trade, 2015; Mri-Tech, 2015).

Average production conditions in the analyzed fish farms are given in Table 2.

The data presented in Table 2 are much better than the average ones for Serbia as a whole. The basic condition for the achievement of similar results is the use of modern breeding technology with the support of the water oxygenation system.

Table 2: Indicators of production conditions and the results achieved in the R1, R2 and R3 fishponds

\begin{tabular}{|l|c|c|c|}
\hline Indicator/Fishpond & DB-Food (R1) & Mri-tech (R2) & Dini-trade (R3) \\
\hline $\begin{array}{l}\text { Production capacity }\left(\mathrm{m}^{2}, \mathrm{~m}^{3}\right) \text { in } \\
\text { exploitation }\end{array}$ & 1,080 & 1,700 & 2,700 \\
\hline $\begin{array}{l}\text { Quantity of water available during } \\
\text { the year }(1 / \mathrm{s})\end{array}$ & $220-600$ & $80-500$ & $110-700$ \\
\hline $\begin{array}{l}\text { Variations in temperature during } \\
\text { the year }\left({ }^{\circ} \mathrm{C}\right)\end{array}$ & $1-18$ & $8-13.5$ & $6-14(2-20)^{*}$ \\
\hline The system for oxygenation & $\begin{array}{l}\text { Active oxygenators, } \\
\text { perforated hoses }\end{array}$ & Perforated hoses & $\begin{array}{c}\text { Active oxygenators, } \\
\text { perforated hoses, } \\
\text { partial recirculation of } \\
\text { water }\end{array}$ \\
\hline Annual oxygen consumption (t) & 30 & 100 & 140 \\
\hline $\begin{array}{l}\text { Coefficient of conversion per annum } \\
\text { for the entire fish farm - FCR ** }\end{array}$ & 1.1 & 1.08 & 1.13 \\
\hline $\begin{array}{l}\text { Losses in the course of fish breeding } \\
\text { from the category of } 1 \mathrm{~g} \text { up to table } \\
\text { fish }(\%)\end{array}$ & $20-30$ & 25 & 25 \\
\hline $\begin{array}{l}\text { Length of breeding (number of } \\
\text { months) }\end{array}$ & $12-14$ & $10-12$ & $10-12$ \\
\hline $\begin{array}{l}\text { Production of table fish per area unit } \\
\left.\text { (kg/m }{ }^{2}\right)\end{array}$ & $45-60$ & $40-60$ & $44-60$ \\
\hline
\end{tabular}

* Before the construction of new penstock. **It was used the medium energy feed. Source: DB FOOD, 2015; Dini-trade, 2015; Mri-Tech, 2015

\section{Economic Results and Structure of Costs}

Based on the data presented in Table 2 as well as other normative data, it can be made an analytical calculation for the production of trout for defined production conditions. For the calculation of economic results there were selected two fish farms with annual production of 50t (M1) and 150t (M2). 
Natural conditions for production and applied technology of production are the key factors that have a crucial impact on the realized production and economic results. Defined conditions and technology of production for which the calculation was made are the following:

- water temperature varies during the year $\left(2^{\circ} \mathrm{C}-18^{\circ} \mathrm{C}\right)$,

- quantity of water varies considerably during the year and there is a lack of water during the summer,

- during the summer (June, July, August, September) there are used devices for the water oxygenation,

- the fish breeding begins by provision of fry of average mass amounts to $1 \mathrm{~g}$ and ends with selling of consuming fish of average mass amounts to $300 \mathrm{~g}$,

- the average length of breeding lasts for 12 months.

Table 3: Analytical calculation of rainbow trout production

\begin{tabular}{|c|c|c|c|c|c|c|c|}
\hline \multicolumn{2}{|l|}{ Model } & \multicolumn{3}{|c|}{ M1 } & \multicolumn{3}{|c|}{ M2 } \\
\hline $\begin{array}{c}\text { Value of production } \\
\text { - VP }\end{array}$ & $\begin{array}{c}\text { Price } \\
\text { (RSD/ } \\
\text { kg) }\end{array}$ & Quantity & $\begin{array}{c}\text { Value } \\
\text { (000 RSD) }\end{array}$ & $\begin{array}{c}\text { Share } \\
(\%)\end{array}$ & Quantity & $\begin{array}{c}\text { Value } \\
\text { (000 RSD) }\end{array}$ & $\begin{array}{c}\text { Share } \\
(\%)\end{array}$ \\
\hline $\begin{array}{l}\text { 1. Consumer trout } \\
(300 \mathrm{~g}),(\mathrm{kg})\end{array}$ & 360 & 50,000 & $18,000.0$ & - & 150,000 & $54,000.0$ & - \\
\hline \multicolumn{2}{|c|}{ Variable costs - VC } & - & - & - & - & - & - \\
\hline $\begin{array}{l}\text { 1. Fry - } 1 \mathrm{~g},(\text { losses } \\
25 \%),(\mathrm{kg})\end{array}$ & 3,600 & 223 & 802.8 & 4.4 & 669 & $2,408.4$ & 4.7 \\
\hline 2. Feed $(\mathrm{FCR}=1,1)$ & 160 & 56,911 & $9,105.7$ & 49.6 & 170,732 & $26,770.8$ & 52.4 \\
\hline 3. Medicines (lump sum) & - & - & 418.4 & 2.3 & - & $1,255.2$ & 2.5 \\
\hline $\begin{array}{l}\text { 4. Chemicals (lump } \\
\text { sum) }\end{array}$ & - & - & 176.4 & 1.0 & - & 529.2 & 1.0 \\
\hline $\begin{array}{l}\text { 5. Oxygen }\left(0.8 \mathrm{kgO}_{2} / \mathrm{kg}\right. \\
\text { fish }),(\mathrm{kg})\end{array}$ & 18,000 & 40 & 720.0 & 3.9 & 120 & $2,160.0$ & 4.2 \\
\hline 6. Seasonal labor & - & - & 244.5 & 1.3 & - & 469.4 & 0.9 \\
\hline 7. Transport of fish & 20 & 50,000 & $1,000.0$ & 5.4 & 150,000 & $3,000.0$ & 5.9 \\
\hline 8. Services & - & - & 576.0 & 3.1 & - & $1,080.0$ & 2.1 \\
\hline 8. Risk reserves & - & - & - & - & - & - & - \\
\hline \multicolumn{2}{|c|}{ Variable costs - Total } & - & $13,043.8$ & 71.0 & - & $37,673.0$ & 73.8 \\
\hline \multicolumn{2}{|l|}{ Fixed costs - FC } & - & - & - & - & - & - \\
\hline 1. Permanent labor & - & - & $4,107.6$ & 22.4 & - & $9,858.2$ & 19.3 \\
\hline 2. Water fee $\left(\mathrm{RSD} / \mathrm{m}^{3}\right)$ & 0.0223 & $9,460,800$ & 211.0 & 1.1 & $28,382,400$ & 632.9 & 1.2 \\
\hline $\begin{array}{l}\text { 3. Depreciation of } \\
\text { buildings }\end{array}$ & - & - & 620.0 & 3.4 & - & $1,860.0$ & 3.6 \\
\hline $\begin{array}{l}\text { 4. Depreciation of } \\
\text { equipment }\end{array}$ & - & - & 321.8 & 1.8 & - & 902.2 & 1.8 \\
\hline 5. Property tax & - & - & 54.7 & 0.3 & & 141.6 & 0.3 \\
\hline Fixed costs - Total & & & $5,315.1$ & 29.0 & & $13,395.0$ & 26.2 \\
\hline \multicolumn{2}{|c|}{ Total costs $-\mathrm{TC}(\mathrm{VC}+\mathrm{FC})$} & & $18,358.9$ & 100.0 & & $51,068.0$ & 100.0 \\
\hline
\end{tabular}




\begin{tabular}{|c|c|c|c|c|c|c|}
\hline Model & \multicolumn{3}{|c|}{ M1 } & \multicolumn{3}{c|}{ M2 } \\
\hline Gross financial result - GFR & - & -358.9 & - & - & $2,932.0$ & - \\
\hline Tax on GFR & & 0 & & & 293.2 & \\
\hline Net financial result - NFR & - & -358.9 & - & - & $2,638.8$ & - \\
\hline
\end{tabular}

Source: Authors' calculation done on the basis of DB FOOD, 2015; Dini-trade, 2015; Mri-Tech, 2015. Remark: All prices without VAT, $120 \mathrm{RSD}=1 €$

Defined natural production conditions are predominantly present conditions in Serbia, while the use of devices for water oxygenation could be considered as the modern technology for Serbia.

Value of production represents the value of table fish being sold. The quantity of table rainbow trout in the model M1 amounts to 50t, while in the model M2 it amounts to $150 \mathrm{t}$. The price of table rainbow trout in Serbia varies during the year, while the wholesale price mostly depends on current supply and price of imported rainbow trout (Turkey and $\mathrm{BiH}$ ). In the past 2 years the wholesale price fco buyer ranged from 340 $\mathrm{RSD} / \mathrm{kg}$ and $380 \mathrm{RSD} / \mathrm{kg}$.

Providing of fry may be carried out only by fish farms that are registered as the breeding organizations with special powers (The Law on livestock, 2009), whereby the price of $1 \mathrm{~g}$ trout fry, including transportation costs, amount to 3,000-4,000 RSD/kg (without VAT). According to the data obtained from the practice, the losses in number of fishes during the breeding period up to the table size amount to $25 \%$. The highest mortality is occurring in the early stages of breeding (up to $10 \mathrm{~g}$ ), which primarily depends on the age at which the young fishes have been transferred from hatcheries in the outdoor pools and the river water for further breeding. The average mass of dead fish is almost always below $50 \mathrm{~g}$, and usually between $30 \mathrm{~g}$ and $40 \mathrm{~g}$.

The gross conversion represents feed conversion ratio (FCR) calculated on the basis of mass of the total produced fish (died and survived ones), while the net conversion represents the same indicator calculated on the basis of survived (sold) consuming trout. The price of feed for trout breeding varies considerably depending on the age fish category and way of purchase. In the trout fishery in Serbia it is predominantly used the high quality feed produced by the famous European producers (Aller Aqua, Coppens, Skretting), where the price depends on the quantity of the food and conditions of payment. In the calculation shown in Table 3 it was taken in account the average price for the medium energy feed (18-20 MJ/kg; digestible energy/kg feed) including the transportation costs.

During the breeding of rainbow trout, in the average case each generation of fish has been treated several times because of the bacterial infections (yersinia, furunculosis, flavobacteriosis) (Jeremić, Radosavljević, 2011; Radosavljević et al., 2013). Selected data on the costs of treatment represent average values obtained from observed fish farms.

In the trout farming there are used different chemical agents for the purpose of disinfection of tools and accessories, vehicles, pools, as well as antibacterial, 
antiparasitic and fungicidal baths. Chemical agents that are usually used are benzalkoniumchloride, formaline, hydrogen-peroxide, peracetic acid (Burka et al., 1997), as well as the chlorine lime (Biočanin et al., 2015) or quicklime for sanitation - microbiological decontamination.

In the period since 2005 to the present days, utilization of oxygen on the trout farms in Serbia is gaining in importance. The use of oxygen in the trout farms is a way for increase of production (Clark, 2003). Although the utilization of oxygen and technical systems has long been in use in the trout fisheries of Europe, Serbia is still ahead of their massive use. Concerning the technical solutions, in Serbia there are most commonly used Turboxygene and Oxy-trans devices for oxygenation of the water, as well as the perforated hoses, and there are also the domestic devices for passive oxygenation of water-Oxy-box (Čanak, 2008). The oxygen consumption depends primarily on the quantity and temperature of water during the period June-October and in the previous ten-year period it has ranged between $0.5 \mathrm{~kg}$ and $1.5 \mathrm{~kg}$ per kilogram of produced table fish.

In order to organize continuous control and the possibility of intervention on the fish farm, it is necessary to have permanently employed at least five fishery workers. With this number of employees it is possible to have two employees per shift three days a week at a time when none of them has used vacation leave. For more demanding operations such as the fish grading, fish bath treatment, stocking, catching of fish, packaging and transport of fish, it is necessary to hire additional labor force, i.e. the seasonal workers.

The consumer rainbow trouts are predominantly supplied freshly caught and chilled at $0-4^{\circ} \mathrm{C}$ in the appropriate packaging. The transportation costs consist of the following cost items: packing, ice, driver per diem costs and costs of transportation vehicle. Depending on the length and distance of transportation, as well as the quantity of fish being transported, in domestic practice these costs generally range between 15-25 $\mathrm{RSD} / \mathrm{kg}$ of market size fish.

Costs of services include the fees for externally engaged technologist, veterinarian and accountant. In the M2 model it is anticipated that the fishpond has the full-time employed accountant.

The cost item marked as "Risk" represents the costs of probability that for some unforeseen reason production experience the total or partial collapse. Practice has shown that events such as flooding, power outages due to storms and fish poisoning due to unscrupulous polluters cannot be predicted in advance. The risk in this case is calculated as an item of variable costs, and essentially represents reduction in production value for the estimated amount of risk (Bohl et al., 1999; Schaeperclaus, Lukovics, 1998). The risk is directly dependent on the degree of production intensity as well as the skill of employees. In the calculation given here the "Risk" item has been listed, but there was not included any amount of this type of variable cost, i.e. the risk costs amount to 0 RSD. 
The costs of water treatement could be significant item depending on the treatement system (Engle et al., 2005). This paper has been charged this item as the labor costs of employees working on the cleaning of basins and removing of the excrements.

The fee for water is the cost which is determined annually and for 2015 it is determined at the level of $0.0223 \mathrm{RSD} / \mathrm{m}^{3}$ of projected or utilized capacity (Regulation on the fees for water in 2015, 2015).

Depreciation of facilities represents depreciation of both production facilities and ancillary ones, such as water-catchment, supply channel, precipitator, basins for breeding, administrative building with warehouse, but also fences, roads, power cable with transformer. Depreciation of equipment includes the annual costs for replacing part of the grader, pools for transport, elevators for fish, devices for killing of fish and other equipment.

Property tax is calculated at the level of $0.4 \%$ of the fishpond real estate value (The Law on Property Taxes, 2001, 2002, 2004, 2007, 2009, 2010). Tax on transportation vehicles is a part of the costs for annual vehicle registration and it is included in the consuming fish transportation costs.

Tax on the gross financial result (GFR) is calculated at the rate of $10 \%$ on the gross financial result if the GFR is the positive value (The Law on Gross Financial Result, 2001, 2002, 2003, 2004, 2010, 2011, 2012, 2013, 2014).

\section{Results and Discussion}

On the basis of the calculated operating costs for consumer trout on two fishpond models (M1 - 50t) and (M2 - 150t), it can be seen that financial result for the M1 model is negative (-358,908 RSD) and for the M2 model is positive $(2,638,799$ RSD).

In the structure of total costs the variable costs account for over $70 \%$, i.e. in the M1 model they amount to $71 \%$, and in the models M2 they amount to $73.8 \%$. A similar percentage share of variable costs in both analyzed models lies in the fact that in both analyzed cases it is present the same technology that causes similar variable costs. For M2 model fixed costs are lower than in the M1 model primarily due to lower labor costs of the full time employees.

The dominant costs in both models are the feed costs, which participate by $50 \%$ in total costs in both models. The second important cost item is the labor costs of the full-time employees which participate by approximately $20 \%$ in total costs. Those two items are followed by the following cost items: transportation, procurement of young fishes, oxygen and depreciation of facilities with a share in total costs between $3-5 \%$ for each mentioned item in both analyzed models.

The cost structure could vary greatly in relation to the natural and economic conditions for performing of the rainbow trout breeding. Thus, Hassan et al., (2007) gives an example that the labor costs account for $29 \%$ and the feed costs account for $28 \%$ in the production of trouts at the analyzed farms in Pakistan. 
In addition to the absolute production and economic performance indicators in the rainbow trout breeding, there can be calculated even the relative performance indicators, e.g. the economic efficiency and profitability of production, capital profitability and labor productivity (Gogić, 2009). In Table 4 there are shown the relative performance indicators calculated for both analyzed models of rainbow trout production.

Table 4: The relative performance indicators of economic efficiency for model M1 and M2

\begin{tabular}{|l|c|c|}
\hline Indicator/Model & M1 & M2 \\
\hline Coefficient of economic efficiency - Ce (VP/TC) & 0.98 & 1.057 \\
\hline The rate of production profitability - Pp (\%) & -1.99 & 4.89 \\
\hline The rate of capital profitability - Cp (\%) & -1.95 & 5.17 \\
\hline Labor productivity (RSD/employee) & 8,333 & 15,000 \\
\hline
\end{tabular}

Source: Authors' calculation based on data from Table 3.

In the case of M1 model (annual production of 50t of trout), the coefficient of economic efficiency is less than $1(\mathrm{Ce}<1)$, i.e. this production is economically inefficient. In the case of M2 model (annual production of 150t of trout), the calculated coefficient of economic efficiency is positive $(\mathrm{Ce}>1)$, i.e. on each $1 \mathrm{RSD}$ of costs is achieved 1.057 RSD of production value.

The rate of production profitability in the case of $\mathrm{M} 1$ model is negative $(\mathrm{Pp}=-1.99 \%)$, since this production has realized the losses. The rate of production profitability in the second case (M2) is positive, i.e. profit participates in the production value by $4.89 \%$. The rates of capital profitability in the case of both models (M1 and M2) behave similarly as the rates of production profitability. Namely, in the M1 model Cp is negative, while in the M2 model $\mathrm{Cp}$ is positive and it amounts to $5.17 \%$.

The labor productivity can be expressed both as natural an economic indicator. In this analysis, the labor productivity is calculated as the natural indicator, i.e. as a ratio of the amount of fish produced per full time employee. At the analyzed trout ponds in Serbia this indicator drastically differs in the case of $50 \mathrm{t}$ trout production and $150 \mathrm{t}$ trout production per year. The main reason for the difference is in the number of full-time employees. Assuming the presence of at least one full-time employee (because of the sensitivity of this production), the production and economic results are significantly burdened due to the high share of labor costs in total costs.

\section{Conclusion}

The production of rainbow trout in Serbia has dated since the first half of the 20th century, but the production in the way it works today (in concrete basins) has been significantly developed after the Second World War. In the recent decade it was slowly adopted in Serbia the modern technologies for trout breeding introduced from developed European countries, and those technologies have enabled achievement of much better production and economic results. 
The aim of this work is to analyze the production and economic results in the rainbow trout farms in Serbia in the case of two production models with an annual production of 50t (M1) and 150t (M2) of trout, on the basis of assumed average production conditions and applied technology for rainbow trout breeding, which involves the use of water oxygenation.

The analysis showed that with the annual production of 50 tons of table trout (M1 model) there were achieved the negative economic results (loss of $-358,908 \mathrm{RSD}$, a negative rate of production profitability of $-1.99 \%$ and negative rate of capital profitability of $-1.95 \%$ ). The labor productivity in this model (M1) is $8,333 \mathrm{~kg} /$ employee, calculated on the basis of the full-time employees. The main cause of negative economic indicators for M1 models lies in the full-time employees' labor costs, as it is necessary to provide the 24 -four-hours monitoring on the pond which influences the number of the full-time employees.

Production of table rainbow trout in the M2 model (150t annual production) shows positive economic results (net profit of $2,638,799 \mathrm{RSD}$, the rate of production profitability of $4.89 \%$ and the rate of capital profitability of $5.17 \%$ ).

In the structure of total costs, the dominant share has the feed (about 50\%), while the labor costs of the full-time employees are in second place (about 20\%). This points to the conclusion that if the Serbian producers want to improve the economic performances of trout production, primarily it is necessary to be reduced the costs of these two items (feed and labor costs).

\section{Literature}

1. Biočanin, R., Šaćirović, S., Ketin, S., Čanak, S., Vignjević-Đorđević, N., Plojović, Š., Nešković, S. (2015): Chemical Processes of Decontamination in the Treatment of Hazardous Supstances. Polish Journal of Environmental Studies, vol. 24, no. 1, pp. 427-432.

2. Bohl, M., Bach, P., Bartmann, K., Eding, E. H., Geier, K., Gropp, J., Hogendoorn, H., Huismann, E. A., Keesen, H. W., Koops, H., Kuhlmann, H., Riedel, D., Riegger, G., Schoorl, R. C., Schumacher, A., Verreth, J., van Weerd, J. H. (1999): Zucht und Produktion von Suesswasserfischen. Verlags Union Agrar. Muenchen. ISBN 3-76900543-0.

3. Burka, J.F., Hammel, K.L., Horsberg, T.E., Johnson, G.R., Rainnie, D.J., Speare, D.J. (1997): Drugs in salmonid aquaculture - A review. Journal of Veterinary Pharmacology and Therapeutics. Blackwell science Ltd., no. 20, pp. 333-349.

4. Clark, L.M. (2003): Comparison of water quality, rainbow trout production, and economics in oxygenated and aerated raceways. Master of Science Thesis, Faculty of the Virginia Polytechnic Institute and State University, December 5, Blacksburg, Virginia. (available at: http://scholar.lib.vt.edu/theses/available/etd-12172003-113917/ unrestricted/ThesisFinal.pdf). 
5. Čanak, S. (2008): Moderna pastrmska proizvodnja. Poljoprivredni kalendar 2008, "Dnevnik - poljoprivrednik" A.D. Novi Sad. pp. 463-464.

6. DB FOOD (2015). Internal documentation of firm and data obtained by an interview.

7. Dini-trade (2015). Internal documentation of firm and data obtained by an interview.

8. Disegna, M., Maurarcher, C., Isabella Procidano, I., Giovanna Trevisan, G. (2009): Caracteristics of production and consumption of organic rainbow trout in Italy. New Medit, Supplement, no. 3, pp. 17-26.

9. Engle, C.R., Pomerleau S., Fornshell G., Hinshaw J.M., Sloan D., Thompson S. (2005): The economic impact of proposed effluent treatment options for production of trout Oncorhynchus mykiss in flow-through systems. Aquacultural Engineering, vol. 32, pp. 303-323.

10. FAO Fisheries and Aquaculture Department [online or CD-ROM]. Rome. [Updated 2014], (Available at: http://www.fao.org/fishery/statistics/software/FishStatJ/en).

11. Fornshell, G. (2002): Rainbow Trout-Chalenges and Solutions, Reviews in Fisheries Science, 10(3-4), pp. 545-557.

12. Gogić, P. (2009): Teorija troškova sa kalkulacijama. ISBN 978-86-7834-070-3. Mladost biro - Beograd, Beograd-Zemun.

13. Hassan A., Ishaq, M., Farooq, A., Sadozai, S.H. (2007): Economics of trout fish farming in the northern areas of Pakistan. Sarhad J. Agric., vol. 23, no. 2, pp. 407-410.

14. Jeremić, S., Radosavljević, V. (2011): Presence of bacterial diseases of fish in the Serbia during the period 2005-2010. V International Conference „Fishery“, Conference Proceedings, Faculty of Agriculture, Belgrade-Zemun, 1-3.6.2011., pp. 409-414.

15. Lukowicz, M. (1994): Site selection and regulation issues for trout and carp farming in Germany. Journal of Applyed Ichtiology, No. 10, pp. 312-318.

16. Marković, Z., Poleksić, V., Živić, I., Stanković, M., Ćuk, D., Spasić, M., Dulić, Z., Rašković, B., Ćirić M., Bošković, D., Vukojević, D. (2009): State of the art of fishery in Serbia. IV International Conference „Fishery“, Conference Proceedings, Faculty of Agriculture, Belgrade-Zemun, 27-29.5.2009., pp. 30-38.

17. Marković, Z., Stanković, M., Dulić, Z., Živić, I., Rašković, B., Spasić, M., Poleksić, V. (2011): Aquaculture and fishery in Serbia - Status and potentials. V International Conference „Fishery“, Conference Proceedings, Faculty of Agriculture, BelgradeZemun, 1-3.6.2011., pp. 36-40.

18. Mri-Tech (2015): Internal documentation of firm and data obtained by an interview.

19. Radosavljević, V., Jeremić, S., Jakić-Dimić, D. (2013): Survey and diagnostics of fish diseases in the Republic of Serbia during the period 2011-2012. VI International Conference „Fishery“, Conference Proceedings, Faculty of Agriculture, BelgradeZemun, 12-14.6.2013., pp. 124-128.

20. Regulation on the fees for water in 2015, "Official Gazette of RS", No. 15/2015.

21. Republički zavod za statistiku Srbije - RZS (2015). Interni podaci dobijeni na osnovu 
zahteva autora.

22. Schaeperclauss, W., Lukovics, M. (1998): Lehrbuch der Teichwirtschaft. ISBN 3800145650. Auflage 4, neubearbeitet, Berlin - Ulmer.

23. Wedekind, H., Hilde, V., Steffens, W. (2001): Present status, and social and economic significance of inland fisheries in Germany. Fisheries Management and Ecology, No. 8, pp. 405-414.

24. The Law on livestock, "Official Gazette of RS", No. 41/2009

25. The Law on Property Taxes, „Official Gazette of RS”, No. 26/01, 45/02-CYC, 80/02, 135/04, 61/07, 5/09 and 101/10).

26. The Law on Gross Financial Result, "Official Gazette of RS”, No. 25/01, 80/02, 43/03, 84/04, 18/10, 101/11, 119/12, 47/13, 108/13, 68/14, 142/14. 


\title{
PROIZVODNI I EKONOMSKI REZULTATI UZGOJA KALIFORNIJSKE PASTRMKE NA RIBNJACIMA SA OKSIGENACIJOM VODE U SRBIJI
}

\author{
Stevan Čanak', Zorica Vasiljevićs ${ }^{4}$ Ibrahim Totič $^{6}$
}

\section{Rezime}

Interesovanje za proizvodnju kalifornijske pastrmke je poslednjih godina u ekspanziji. Jedno od uobičajenih nedoumica investitora je za koju veličinu ribnjaka da se odluče. Da bi mogli da pravilno odluče, potrebno je da investitori raspolažu proizvodno i ekonomskim podacima/pokazateljima koji mogu biti ostvareni sa različitim količinama proizvedene ribe. Ovih podataka nažalost nema dovoljno u literaturi. Ovaj rad se bavi ekonomskim aspektima proizvodnje kalifornijske pastrmke korišćenjem moderne tehnologije sa oksigenacijom vode.

Tema istraživanja ovog rada je poređenje ekonomskih rezultata ribnjaka različitih veličina na kojima se proizvodi konzumna kalifornijska pastrmka. U svrhu ove analize korićen je metod analitičke kalkulacije. Prilikom analize su definisana dva proizvodna modela, MI sa godišnjom proizvodnjom 50t i model M2 sa godišnjom proizvodnjom od $150 t$ konzumne kalifornijske pastrmke.

Rezultati analize su pokazali da model M2 ima bolje ekonomske pokazatelje. U strukturi ukupnih troškova, dominantno mesto zauzima trošak hrane (50\%), dok su troškovi stalno zaposlenih na drugom mestu (20\%). Ukoliko proizvođači u Srbiji žele da poboljšaju ekonomske rezultate proizvodnje pastrmke, na prvom mestu je poželjno da smanje troškove hrane i stalno zaposlenih radnika.

Ključne reči: rainbow trout, production conditions, economic effects, water oxygenation.

4 Asistent. dr Stevan Čanak, Departman za Hemijsko-tehnološke nauke, Državni univerzitet u Novom Pazaru, Vuka Karadžića bb., 36300 Novi Pazar, Republika Srbija, tel: +381 20317752. email: scanak@np.ac.rs

5 Redovni prof. dr Zorica Vasiljević, redovni profesor, Poljoprivredni fakultet univerziteta u Beogradu, Nemanjina 6, Zemun, Republika Srbija, tel: +381-11-2615-315/Ext. 412, E-mail: vazor@agrif.bg.ac.rs

6 Docent dr Ibrahim Totić, Departman za Ekonomske nauke, Državni univerzitet u Novom Pazaru, Vuka Karadžića bb., 36300 Novi Pazar, Republika Srbija, tel: +381 20317752. email: itotic@np.ac.rs 